\title{
A reversible cause of "vascular dementia"
}

\section{Figure 1 Pretreatment head CT and angiogram}

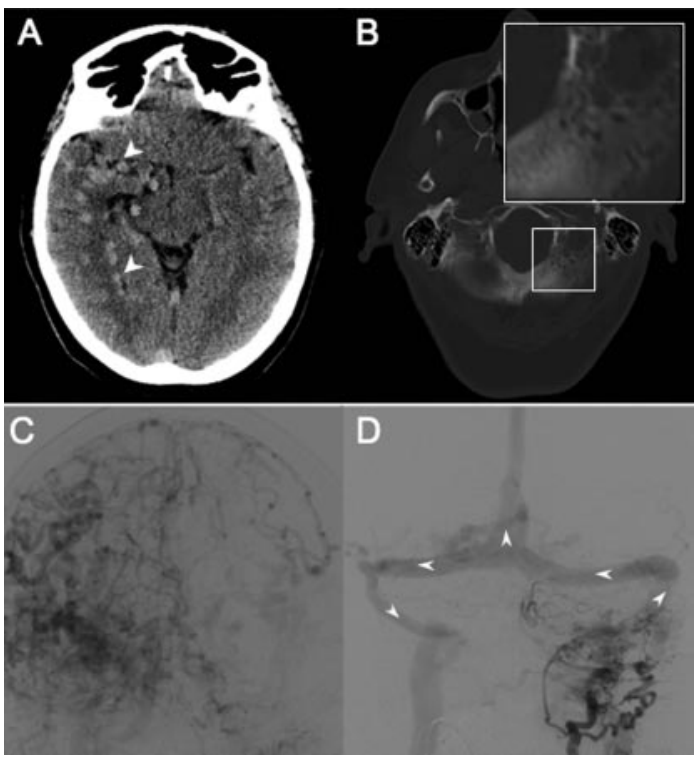

(A) Plain head CT demonstrating dilated cortical veins (arrowheads). (B) Transosseous vascular channels in left occipital bone (inset). (C) Angiogram of cerebral venous phase with dilated cortical veins and absent drainage via dural sinuses. (D) Extracranial feeders to dural arteriovenous malformation with reflux into dural sinuses (arrowheads: retrograde flow).

\begin{tabular}{|ll|}
\hline Figure 2 & $\begin{array}{l}\text { Posttreatment head CT and } \\
\text { angiogram }\end{array}$
\end{tabular}

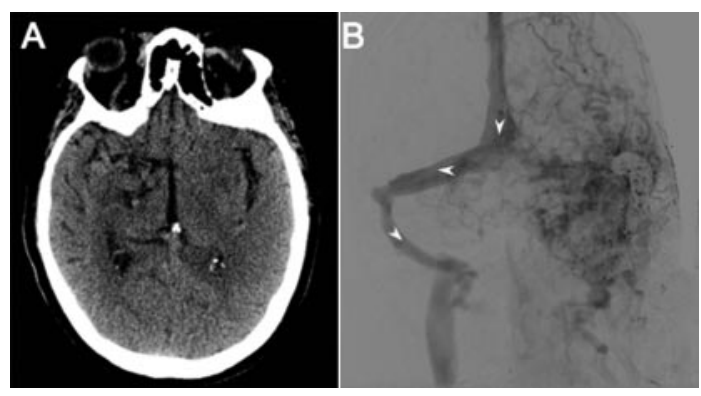

(A) Post-coiling head CT demonstrating decreased caliber of cortical veins. (B) Post-coiling cerebral venous phase with normal venous drainage via dural sinuses (arrowheads: anterograde flow).

A 63-year-old woman presented with progressive dementia over 2 years. Plain head CT demonstrated dilated parenchymal vessels and vascular channels in the left occipital bone (figure 1, A and B). Angiography confirmed a dural arteriovenous malformation (dAVM) centered on the left sigmoid sinus with reflux into all venous sinuses (figure 1, C and D). Cerebral venous drainage was rerouted via cortical veins. Coil occlusion of the recipient venous pouch restored normal venous drainage and reduced the caliber of cortical veins (figure 2, $\mathrm{A}$ and $\mathrm{B})$, helping improve cognitive function.

Dementia secondary to dAVMs results from venous hypertension causing ischemic neuronal dysfunction. ${ }^{1}$ Fistula obliteration may reverse the dementia.

\section{A.Y. Poppe, MD, FRCPC, T.W.J. Watson, MD, FRCPC, M.E. Hudon, MD, FRCPC, V. Puetz, MD, W. Wang, MD, Calgary, Alberta, Canada}

Disclosure: The authors report no disclosures.

Address correspondence and reprint requests to Dr. A.Y. Poppe, Calgary Stroke Program, Department of Clinical Neurosciences, Foothills Medical Centre, University of Calgary, Calgary, Alberta, Canada, T2N 2T9; Alexander.Poppe@calgaryhealthregion.ca

1. Hurst RW, Bagley LJ, Galetta S, et al. Dementia resulting from dural arteriovenous fistulas: the pathologic findings of venous hypertensive encephalopathy. AJNR Am J Neuroradiol 1998;19:1267-1273. 


\section{Neurology}

A reversible cause of "vascular dementia"

A. Y. Poppe, T.W.J. Watson, M. E. Hudon, et al.

Neurology 2008;71;226

DOI 10.1212/01.wnl.0000317098.87419.68

This information is current as of July 14, 2008

\section{Updated Information \&} Services

References

Subspecialty Collections

Permissions \& Licensing

Reprints including high resolution figures, can be found at: http://n.neurology.org/content/71/3/226.full

This article cites 1 articles, 0 of which you can access for free at: http://n.neurology.org/content/71/3/226.full\#ref-list-1

This article, along with others on similar topics, appears in the following collection(s):

\section{Arteriovenous malformation}

http://n.neurology.org/cgi/collection/arteriovenous_malformation $\mathbf{C T}$

http://n.neurology.org/cgi/collection/ct

Vascular dementia

http://n.neurology.org/cgi/collection/vascular_dementia

Information about reproducing this article in parts (figures,tables) or in its entirety can be found online at:

http://www.neurology.org/about/about_the_journal\#permissions

Information about ordering reprints can be found online:

http://n.neurology.org/subscribers/advertise

Neurology ${ }^{\circledR}$ is the official journal of the American Academy of Neurology. Published continuously since 1951, it is now a weekly with 48 issues per year. Copyright . All rights reserved. Print ISSN: 0028-3878. Online ISSN: 1526-632X.

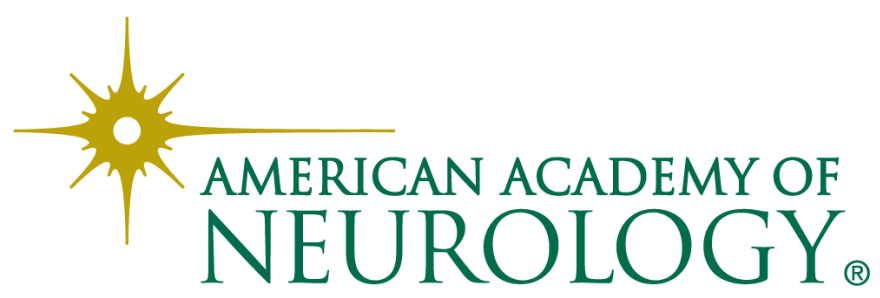

